\title{
The General Election Commission Role of Political Communication in Preventing Absent Voters in Sragen Regency
}

\author{
Dr. Sutopo, MS and Drs. Roso Prajoko, M.Si \\ Postgraduate Program of Communication, Faculty of Social and Political Sciences, Universitas Sebelas Maret \\ (no emails)
}

Keywords: Political communication, abstention behavior, local general election.

\begin{abstract}
The phenomenon of absent voters has emerged since the New Order era and has continued to shade the Election Commission during the national and local elections' processes. This study aims to explain the factors behind the phenomenon of absent voters in Sragen regency during the election. The research used qualitative method. It was conducted by using the case study approach, while the data were collected from in-depth interviews, documentation, records, and archives from KPU (General Election Commission) during the 2015 Sragen Election. Based on the absent voters' data, the names of the latter were identified and a sample of them were selected as informants. The data were analyzed by using interactive methods from Miles and Huberman (1992). The analysis results were based on Elaboration Likelihood Model (ELM) theory that influences voting in the election, among which are: 1) the voters' effort to disseminate the information given by KPU starting from the preparation stage of the election, 2) the information given by KPU were not equally distributed. The writer's suggestions and recommendations include: 1) KPU to socialize the election more properly, 2) Socialization budget to ease the information dissemination needs to be addressed by the government.
\end{abstract}

\section{INTRODUCTION}

Problems of absent voters (golongan putih, Golput) have become a part of thought for the holders of direct election in local, regional, presidential, or legislative level. Elections of the Local and Regional Head of District (Pemilihan Kepala Daerah, Pemilukada), which are direct in nature, were recently held simultaneously across Indonesia. Local and regional elections are enabling the people to be actively involved in the decision-making process in the local governmental organization. Unfortunately, each time the elections were held, the problem of absent voters arises. The considerably high number of absent voters, which can be interpreted by voters' low participation level in the local, regional, and national elections often haunts the election holders.

Golput, an abbreviation of absent voters or golongan putih (white group), was initially a moral force initiated by students and scholars namely Arief Budiman, Imam Waluyo, Julius Usman, Husein Umar, and Asmara Nababan. The movement's founding was based on several reasons, such as their disappointment regarding the election process which, for them, did not bring any changes towards the people's prosperity. In addition, they could not find any place or any political party to facilitate their political aspirations. The logo for Golput is a pentagon, similar to the logos of Golkar (Golongan Karya, a political party) and IPKI (Ikatan Pendukung Kemerdekaan Indonesia, Association of Supporters of Indonesian Independence) (Hussen, 2014).

There are two groups of absent voters in Indonesia. The first group is the common absent voters, consisting of people who do not use their voting rights for reasons besides politics, such as business or economics. The group's level of political ability does not reach the level of analysis in determining their choice based on the candidates' expertise. The second is called elective absent voters. They are motivated by their disappointment with the existing political parties (Novel Ali, 1999). They have both political views and choices but choose not to use their voting right as a form of protest. The protest does not only come from individual loyal to a political party, but also from swing voters who do not have a suitable candidate (Husein 2014:310).

The statement, however, can sustain since the voters were disappointed by either the existing political parties or their candidates. Their sentiment of disappointment makes them decide not to choose or to vote. The sentiments were added with the fact 
that in recent developments, there is no clear definition of vision, mission, programs, and platforms between one political party and another. It is pursuant to Law No. 2 of 2008 on Political Parties, Chapter 1, point (1), stating that a political party is defined as "a national organization voluntarily formed by a group of Indonesian citizens based on the similarity of will and aspirations to fight for and to defend political interests of its members, the society, nation, and to preserve the unity of Unitary State of the Republic of Indonesia based on Pancasila and 1945 Constitution of the Republic of Indonesia".

The data of absent voters during the Central Java Gubernatorial Election in Sragen regency could be calculated from the total number of voters $(782,756$ people), subtracted by those going to polling stations (407,914 people), making 375,271 people as absent voters, or $47.95 \%$ of the total number of voters. This problem was also found on December $9^{\text {th }}, 2015$ Simultaneous Local and Regional Election. In Sragen regency, the number of absent voters was considerably high.

The trend of high absent voters' number started in 2006, which showed a participation level of $71.60 \%$. It was, however, decreased in 2011 to the level of $71.00 \%$. In 2015 Simultaneous Election, Sragen General Election Commission (KPU Sragen) successfully held regency elections, which resulted in the win of Dr. Kusdinar Untung Yuni Sukowati-Dedy Endrianto. Even though it was considered successful, the percentage of absent voters in this election was $29.6 \%$, while the voters' participation was $70.4 \%$. It was far from the target set by the National General Election Commission (KPU RI) which had targeted $77.5 \%$ voters' participation nationally (KPU, 2015).

From the high number of absent voters' phenomenon in Central Java and its subsequent phenomenon during the 2015 Simultaneous Local and Regional Election, the researchers are interested in studying the role of political communication by KPU. During the 2015 election in Sragen Regency, it was found that the absent voters have reached $29.6 \%$ of total voters, amounting to 232,503 people.

\section{METHODS}

Research methodology, in principle, is a scientific way to obtain data with certain intention and benefit based on scientific facts or signs (Sugiyono, 2014). The researchers are using qualitative method as the latter is able to be used as a way to both collect and analyze qualitative data in the form of words to describe human actions (Afrizal 2016:31-33). The researchers have collected emic data based on informants as the main data source and not using the researchers' own view (Sugiyono, 2014: 6). The researchers obtained information about the causes of absent voters' attitudes from informants based on documentation data and in-depth interviews, not from the researchers' interpretation alone.

Research location is a place where the research is conducted. According to Afrizal (2016: 128), it can also be described as a setting or research context. This research was conducted in five sub-districts that has the lowest voting participation rate or the highest absent voters' percentage during an election in Sragen Regency. The five following sub-districts are Sukodono $(65.10 \%$ of total voters), Sambirejo (65.39\% of total voters), Tanon $(65.44 \%$ of total voters), Plupuh $(66.31 \%$ of total voters), and Mondokan (67.69\% of total voters). From 20 subdistricts in Sragen regency, these five sub-districts were chosen by the researchers because of its high voters' absence percentage, representing the highest numbers of all sub-districts.

This research was conducted from March to June of 2017. By using the qualitative research, this research is aiming to give an in-depth explanation regarding a phenomenon through an inherent data collection (Kriyantono 2006:58). In this research, the researchers did not primarily rely on the number of informants interviewed but also had more special importance on the depth of data quality. Had the collected data were able to explain the phenomenon, then additional informants were not needed (Sugiyono, 2014). This research is trying to understand the events which the research subject or informants had experienced, from the attitudes of the voters who did not use their right to vote or who have chosen to be absent voters in 2015 Sragen Regency Election.

The research examines on how KPU Sragen (General Election Commission Sragen) as the main political communicator is performing their function in disseminating information in the form of political socialization and education towards the local community. This social function is in relation to the agency's responsibility as the local election holder. Apart from KPU, this research also examines the attitude of Sragen Regency residents, spreading across 20 sub-districts in 2015 Local Election. The theories employed in the study are political communications in the application of Elaboration Likelihood Model theory (ELM) and Sragen resident's psychological terms to become absent voters. 


\subsection{Political communication}

Political communication is a communication process with an aim to influence public's knowledge, beliefs, and actions within the political sector.

\subsection{Elaboration Likelihood Model}

Elaboration Likelihood Model (ELM) is a persuasive theory which processes a message persuasively by using different ways, by activating each route in order to influence people's political outlooks. (Griffin, 2012). The theory is used to predict the time a person responds or does not respond to a message from a pursuer (Littlejohn \& Foss, 2008:72). In the Strong Negative Attitude Change Type theory, in this phase, the message receiver will not respond even after the messenger has raised strong argumentations and facts. In this manner, voters as the message receiver react apathetically.

As the messenger, KPU should be able to encourage people by showing accurate and precise data (Strong Positive Attitude Change theory). They should also deliver the message in a good manner to influence the people's participation in the local election. If the message dissemination by a central route cannot be conducted, the messenger can improve both of its human resources' and community resources' credibility outside of the message content.

A message can be defined as a dimension of communication content that is not only able to be explained by using verbal sentences but also able to be served non-verbally (Thomas 2016:41). Based on this definition, a political message is a statement given by either an agency or the government both written and verbally that contains political elements that delivered to the people. Political speeches and debates, for example, are some examples of information dissemination regarding the Election Law. Accordingly, KPU as a communicator should give proper education through socialization towards the voters in the local election.

\section{RESULTS AND DISCUSSIONS}

In this Elaboration Likelihood Model (ELM), KPU has conducted two models of communication, namely the central route and the peripheral route. Both models can affect a person in a different way during the message processing. ELM has two routes of messages, with an explanation of how the receiver can receive the message given.

\subsection{Main communication model by KPU}

In preventing the absent voters, KPU has conducted many forms of persuasive communication so that the political message related to the local election can be received by the people. Introducing the political system to the people in the local election process is one of KPU's responsibilities. KPU is responsible for the process of political education, which in this manner is voter education to raise the people's participation rate.

To prevent absent voters, KPU has conducted persuasive socialization to the residents by giving information regarding the 2015 Local Election. For example, KPU has given information regarding the election schedule, obtaining data from eligible voters, and encouraging the residents to use their voting rights during the election. This socialization process was then followed by joint campaign by KPU and candidate pairs in 20 sub-districts. The event was conducted until a day before the election.

"KPU has conducted the socialization about the stage within the local election process. This is one of the ways to improve people's interest to vote." (Informant 4: Ibnu Prakosa, June 14, 2017).

KPU has always encouraged the residents to use their voting rights, both through TV or radio stations and printed media. In accordance with the latter, KPU Sragen has also given socialization about the candidate's profile, supporting political parties, candidate's vision and mission, stages of election process until the Election Day, as well as encouraging the residents to participate in the 2015 Sragen Regency Election. There were billboards that contains information about the candidate pairs and their supporting political parties. These billboards were intended to raise people's awareness and to inform them about the process of the election. There were two types of billboards: 1) Billboards that informs Voter Data Renewal stages, being put across 208 Village Administrative Units (Kelurahan) in Sragen Regency, 2) Billboards that contains discern vision and mission of the candidate pairs and the encouragements to vote on December 9th, 2015, also being put across 208 Village Administrative Units (Kelurahan) in Sragen Regency.

The socialization was also conducted by holding campaigns across 20 sub-districts in Sragen Regency and was facilitated by KPU. In this campaign, the candidates were allowed to utilize masses with the permission of KPU. Besides, KPU also conducted socialization towards sub-district level and village 
level election holder in which they introduced the candidates in the 2015 election.

"There were socializations held by KPU that encouraged the people to vote on December 9th, 2015 , including candidate introduction. It was usually conducted in the Sub-district Administrative Office, but sometimes also disseminated by the village officials through meetings in RT and kelurahan." (Informant 9: Dwi Purwanto, June 14, 2017).

In addition, one informant also stated that:

"KPU's socializations were conducted at the village level. Supporting political parties of each candidate were also conducted the same socialization to gather people's support for their respective candidate. To some extent, the political parties also put up posters to gain their support." (Informant 8: Sunarno, June 14, 2017).

The candidate pairs were also required to take part in the candidate debates that were also broadcasted by TATV Surakarta.

"The intention of the live broadcast was to introduce the candidates, their vision, and mission to the residents." (Informant 4: Ibnu Prakosa, June 14, 2017).

The debate was useful for socializing the plan of each candidate. Each of the debate also has different themes It was expected that the debates would provide comprehensive information for the people to consider their choice on December 9th, 2015 Election.

"On the last local election, I was not interested in any political parties. I was more interested in the candidates. Since I did not really know who they were, I chose to absent. In addition, the candidates came from a different neighborhood. In the legislative council member election, however, one of the candidates is originated from my neighborhood." (Informant 2: Sunardi, June 15, 2017).

Based on the interviews, the researchers were able to explain that the people did not know the candidates very well, almost distant, since the candidates never visit their area to socialize or to gather support. The distance made the people be unwilling in using their voting rights in the local election. The candidates are expected to visit the residents and communicate with them directly. It is different from the Regency's Legislative Council member election. The residents have met all candidates that came to the area directly, from one home to another, which sympathize the people.

\subsection{External factors}

In Elaboration Likelihood Model, one of the considerable factors that influence the voters is the external factors. These factors include the election budget, regulations concerning people's voting rights, and people's education and economic level.

\section{CONCLUSION}

The absent voters' attitude in political and psychological terms during the 2015 Sragen regency election, could be caused by several factors based on the application of Elaboration Likelihood Model (ELM) AND Political Psychology. The factors include the low efforts in distributing information through the socialization process by KPU Sragen. In addition, the persuasive communication by KPU tends to be distributed unevenly. This makes the information dissemination did not reach every level, but indeed reached some villages in each sub-district. Therefore, the information can be considered unequally distributed at the sub-district level.

\section{REFERENCE}

Afrizal. 2016. Metode Penelitian Kualitatif. Jakarta: PT Rajagrafindo Persada

BPS, 2016. Statistik Daerah Kabupaten Sragen 2016. Sragen: BPS Kabupaten Sragen

Culbert, Gar, Pomirchy, Michael, Sonenshein, Raphael. 2015. Determinants of Political Participation in Urban Politics: A Los Angeles Case Study. California Journal Of Politics and Policy, Vol. 7 No.2. pp. 1-16.

Effendy, Onong Uchjana. 2006. Ilmu Komunikasi Teori dan Praktek. Cetakan ke 19 Bandung: PT Remaja Rosdakarya.

Griffin, Emory A., 2012. A First Look at Communication Theory, $8^{\text {th }}$ edition. New York: McGraw-Hill.

H. Soebagio. 2008. Implikasi Golongan Putih Dalam Perspektif Pembangunan Demokrasi Di Indonesia. Program Pascasarjana, Universitas Islam

KPU Propinsi Jawa Tengah, 2013. Pilkada Jawa Tengah, Semarang

Littlejohn, SW., Foss Karen A, 2011. Theories of Human Communication. 9th Edition, Longrove, Illionis: Waveland Press. USA.

Nimmo. 2010. Political Communication and Public Opinion and America, Bandung: Remaja Rosdakarya.

Novel Ali, 1999, Peradaban Komunikasi Politik, Bandung: Remaja Rosdakarya

Sugiyono 2014. Metode Penelitian Kuantitatif, Kualitatif dan $R \& D$. Bandung: Alfabeta Bandung. 